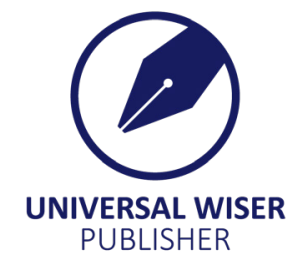

\title{
Effect of Entomopathogenic Fungi on the Survival of Helicoverpa Armigera (Lepidoptera: Noctuidae)
}

\author{
I. Lagogiannis, A. Ntoukas, I. Zampara, S. Mantzoukas* \\ Department of Pharmacy, School of Health Sciences, University of Patras, Patras 26504, Greece \\ E-mail: sdmantzoukas1979@gmail.com,mantzoukas@upatras.gr
}

\begin{abstract}
The use of entomopathogenic fungi for the control of insect pests has been the subject of extensive scientific research for their potential effectiveness, safety and pest selectivity. These microorganisms infect insects in a way which includes a sequence of events, resulting in the disruption of the regular functions of the host and its ultimate death. Our nine-day experiment focused on the effect of three fungal species, Beauveria bassiana, Metarhizium robertsii and Isaria fumosorosea, on the survival of Helicoverpa armigera larvae in vitro. The fungi were sprayed each at six different concentrations $\left(10^{3}, 10^{4}, 10^{5}, 10^{6}, 10^{7}, 10^{8}\right.$ conidia $\left./ \mathrm{ml}\right)$ on $\mathrm{L}_{2}$ larvae. Statistical analysis produced varying degrees of larval mortality which exhibited a clear dose-dependency. Especially the high-end concentrations of $10^{7}$ and $10^{8}$ conidia $/ \mathrm{ml}$ of all three fungi were very pathogenic, with larval mortality ranging between 87 and $100 \%$ at nine days. Our results add to the direction of incorporating entomopathogenic fungi in the toolbox of biological pest control.
\end{abstract}

Keywords: entomopathogenic, fungi, Beauveria, Metarhizium, Isaria, Helicoverpa

\section{Introduction}

The majority of insect diseases (approximately $60 \%$ ) is induced by pathogenic fungi ${ }^{[1]}$. Consequently, research in agricultural pest control has been increasingly geared towards the investigation and incorporation of biological control agents such as parasitoids, fungi, bacteria and viruses, as pest control tools in place of or in conjunction with chemical insecticides. Entomopathogenic fungi which by nature infect and often kill insects and other arthropods ${ }^{[2]}$, while remaining non-pathogenic to plants and relatively non-toxic to humans and animals ${ }^{[3]}$, display many advantages over other biological and chemical products, albeit they are relatively underutilized.

Infection of an insect by an entomopathogenic fungus results from the contact of the fungal spores with the insect's cuticle. The process by which insect pathogens enter the insect consists of a sequence of events which interact with many biotic and abiotic factors. However, the precise way in which a pathogenic fungus recognizes the host is unknown. It has been observed that the fungus produces an elicitor which is detected by membrane-bound receptors on the host cell. Through this binding, the production of enzymes by the pathogen is elicited. It is thus that the pathogen invades the cell wall ${ }^{[4]}$.

The growth cycle of entomopathogenic fungi in vivo comprises the following steps: (a) adhesion of the conidia to the host cuticle; (b) formation of a germ tube; (c) cuticle puncture; (d) production of enzymes to facilitate the invasion process; (e) vegetative growth inside the insect; (f) nutrient use and installation; (g) production of toxins and infectious agents to suppress the host defense; (h) production of external conidiophores after the death of the insect ${ }^{[5,6,7-9]}$. Three to seven days post infection, the host dies from starvation ${ }^{[10-12]}$. The result of the infection depends on the fungus's genetic ability to infect, on the insect's ability to defend itself and on many biotic and abiotic factors and interactions such as low relative humidity and the inability to use available nutrients in the insect's cuticle ${ }^{[10,13-15]}$.

Helicoverpa armigera (Hübner) (Lepidoptera: Noctuidae) features among the most harmful agricultural pests ${ }^{[16]}$. It is a geographically widespread (Europe, Asia, Africa and Oceania) ${ }^{[16]}$, highly polyphagous moth whose host species include a wide range of economically important crops such as cotton, maize, chickpea, tomato, sorghum, sunflower etc. Females lay their eggs on the fruits and flowers of these crops where hatched larvae start to feed causing significant agricultural damage ${ }^{[17]}$. Helicoverpa armigera has been attributed the pest status not only because of its ability to attack a wide range of hosts from various families but also for its resistance to insecticides ${ }^{[18,19]}$.

The aim of the study is to study how different doses of the entomopathogenic fungi, Beauveria bassiana (Bals.- Criv.)

Copyright (C2020 S. Mantzoukas, et al.

DOI: https://doi.org/10.37256/amtt.122020334

This is an open-access article distributed under a CC BY license

(Creative Commons Attribution 4.0 International License)

https://creativecommons.org/licenses/by/4.0/ 
Vuill. (Hypocreales: Cordycipitaceae), Metarhizium robertsii (Bisch., Rehner \& Humber) (Hypocreales: Clavicipitacae), and Isaria fumosorosea Wize (Hypocreales: Cordycipitaceae) affect the survival of Helicoverpa armigera larvae in vitro. Beauveria, Metarhizium, and Isaria are three of the most important genera utilized as biological control microbial agents, as they have been reported to successfully infect several species of many insect orders all over the world ${ }^{[2,20-23]}$.

\section{Materials and methods}

\subsection{Entomopathogenic microorganisms}

We selected the fungal species Beauveria bassiana (STRAIN: B28AZS), Metarhizium robertsii (STRAIN: MET) and Isaria fumosorosea (STRAIN: Agios Stefanos), as they are the most commercially used, they infect a wide range of hosts and they are used as biological control agents for crop pests ${ }^{[10]}$. The entomopathogenic fungi were isolated by using stored pests as bait (Stored Pest Bait method) ${ }^{[24]}$. Conidia identification was carried out stereoscopically. The isolates were maintained in Petri dishes on SDA medium (Sabouraud Dextrose Agar, Oxoid) at $3 \pm 1{ }^{\circ} \mathrm{C}$ and they were renewed monthly.

\subsection{Preparation of suspensions of pathogens}

Sixty-five grams of Sabouraud Dextrose Agar (Oxoid, USA) were used to prepare the growth substrate, which was dissolved in $1000 \mathrm{ml}$ of sterile water and heated to boiling point. It was distributed in conical flasks and autoclaved in the oven for $20 \mathrm{~min}$ at $1.5 \mathrm{bar}$ pressure, at $121^{\circ} \mathrm{C}$. In order to prepare the suspensions for the needs of the experiments, the fungi were cultured on $9 \mathrm{~cm}$ SDA Petri dishes, secured with Parafilm for protection against contamination, and allowed to grow in the dark for 15 days at $25^{\circ} \mathrm{C}$. Conidia were collected from the cultures after 15 days. The suspensions were prepared by scraping conidia from the surface of the Petri dishes using a sterile metal hook. The conidia were transferred to $500 \mathrm{ml}$ bottles containing $100 \mathrm{ml}$ of sterile water and Tergitol®NP9 $0.05 \%$. The conidial suspension was filtered through several layers of sterile cloth (organ-small cross-holes) before it was homogenized for 5 min using a magnetic stirrer $^{[25]}$. Finally, a Neubauer hematocytometer was used in an optical microscope (400x) to determine the desired doses. Conidial germination was high. This was assessed by examining the fungal conidia using an optical microscope (40x) after incubation in the dark and after $24 \mathrm{~h}$.

\subsection{Helicoverpa armigera rearing}

Helicoverpa armigera individuals were originally collected from tomato fields in Mirtia, Ilia, Greece (37.702267, 21.359392), and their taxonomy was established stereoscopically by examining larvae (Figure 1). They were reared on an artificial substrate in laboratory conditions. All stages were maintained in a room with constant temperature $25 \pm 1{ }^{\circ} \mathrm{C}$, humidity 60 to $70 \%$ and photoperiod $16: 8 \mathrm{~h}$ light: dark. Plastic trays $\left(26 \times 51 \mathrm{~cm}\right.$ wide, $\left.4 \times 4 \times 5.5 \mathrm{~cm}^{3}\right)$, tightly covered with fine muslin cloth for aeration, were used for larval rearing. Two days before the treatment, the larvae were allowed to feed on 4-week-old green tomato fruit so that they could acclimatize to the natural diet again. The newly emerged pupae were removed from the diet and they were transferred to empty glass vials sealed with cotton wool. They were placed in the incubator, maintained at $24 \pm 3^{\circ} \mathrm{C}, 70 \pm 5 \% \mathrm{RH}$ and L14: D10 until adult emergence ${ }^{[26]}$. The newly developed adult moths and their sex were recorded daily and transferred to boxes to obtain eggs for future progeny development.

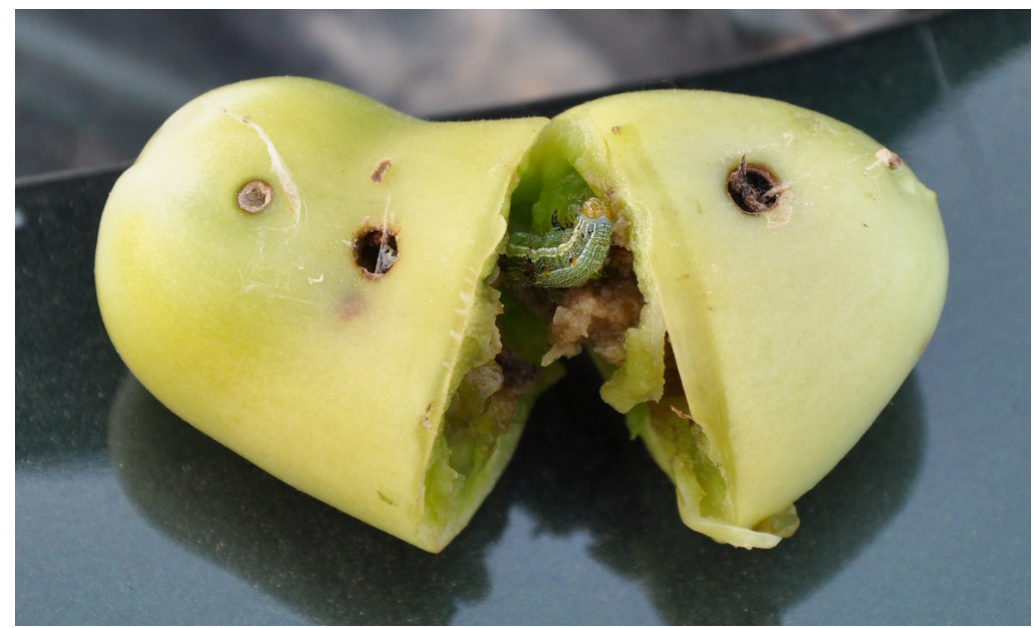

Figure 1. Larvae of $H$. armigera collected from Mirtia, Ilia, Greece for the initial laboratory rearing 


\subsection{Determination of susceptibility of $\mathrm{H}$. armigera to entomopathogenic fungi in a range of doses}

Conidial suspensions of concentrations of $10^{3}, 10^{4}, 10^{5}, 10^{6}, 10^{7}, 10^{8}$ conidia/ml were prepared for the entomopathogenic fungi B. bassiana, M. robertsii and I. fumosorosea. The range of doses was selected to determine the infectivity of the fungi. Ten $\mathrm{L}_{2}$-aged larvae of $\mathrm{H}$. armigera were sprayed with a $10 \mathrm{ml}$ suspension from each entomopathogenic microorganism using sterile sprays $(500 \mathrm{ml})$ and were placed in $9 \mathrm{~cm}$ sterile Petri dishes. The prepared suspensions were applied with a Potter spray tower (Burkard Manufacturing Co. Ltd., Rickmansworth, Hertfordshire, U.K.) at $1 \mathrm{kgf} \mathrm{cm}^{-2}$. They were kept at $25 \pm 1{ }^{\circ} \mathrm{C}$ and humidity $75 \%$, and they were provided with a natural diet. For each concentration, 10 repetitions of 10 individuals were performed. Survival was performed every three days. Control larvae of the same age were sprayed with $10 \mathrm{ml}$ of surfactant solution (Tergitol NP9 $0.05 \%$ ). The dead larvae were removed and surface sterilized using $2 \%$ sodium hypochlorite for a few seconds to avoid the development of saprophytic fungi. In order to determine the cause of death and to determine the pathogen, each dead larva was examined using a stereoscope.

\subsection{Statistical analysis}

The analysis of variance of the averages of larval mortality values was performed using the concentration and time variation analysis technique. The SPSS statistical package (SPSS Inc., IL, USA, version 23.0) was used to analyze the variance of the data. The data, where deemed necessary, were appropriately converted (arcsin) to meet the requirements of the parametric analysis for equal variations between treatments. Comparison of mean values compared for statistically significant or non-significant differences between the parameters under study was performed with Tukey test for significance level $\alpha=0.05$. The efficacy of each fungus on $\mathrm{H}$. armigera larvae was calculated by Abbott's formula ${ }^{[27,28]}$. The Kaplan-Meier method (non-parametric) was also chosen to determine the mean survival time of H. armigera larvae treated with the pathogenic doses. The results of the survival function were compared with the Breslow-Gehan distribution test (SPSS v. 23.0). Abbott's formula for effectiveness determines that: Effectiveness: [1- (Final treated population/Initial treated population $\mathrm{x}$ Initial control population/Final control population)].

\section{Results - discussion}

To establish the effectiveness of the different doses of the entomopathogenic fungi, larval mortality as well as the control were observed daily until the end of the experiment. This was the first time that M. robertsii was tested against larvae of $\mathrm{H}$. armigera.

The mortality of the control larvae $\left(\mathrm{H}_{2} \mathrm{O}+\right.$ Tergitol NP9 $\left.0.05 \%\right)$ was $4 \%$ at the end of the experiment. By contrast, the three entomopathogenic fungi resulted in varying degrees of larval mortality which was proportional to the concentration used. Larval mortality ranged from $3.4 \%$ (three days) to $100 \%$ (nine days) at all doses. All applied doses differed significantly from the control, with the exception of the lower doses of $10^{3}, 10^{4}$ and $10^{5}$ which had produced zero mortality by day three (Table 1). In the case of the entomopathogenic fungus B. bassiana, the results showed that, while at three days, only the higher doses of $10^{6}, 10^{7}$ and $10^{8}$ induced a mortality significantly different from the control, at six and nine days, all concentrations proved to be significantly lethal $(\mathrm{F}=2.901, \mathrm{df}=12.42, \mathrm{P}<0.001)$. Larval mortality at $10^{8}$ ranged between 23 (three days) and 97\% (nine days). By contrast, in the treatment with M. robertsii, larval mortality $\left(10^{8}\right)$ ranged between 20 (three days) and 97\% (nine days) $(\mathrm{F}=9.915, \mathrm{df}=12.42, \mathrm{P}<0.001)$, and in the treatment with $\mathrm{I}$. fumosorosea, larval mortality $\left(10^{8}\right)$ was between 13 (three days) and $100 \%$ (nine days), which differed significantly from the control at all doses and at all measurements $(\mathrm{F}=10.270, \mathrm{df}=12.42, \mathrm{P}<0.001)$. Overall, at nine days, the doses of $10^{7}$ and $10^{8}$ in the treatments with B. bassiana, M. robertsii and I. fumosorosea were significantly more pathogenic than all other doses in terms of mortality (Table 3). Statistically significant differences were observed between doses for all fungi $(\mathrm{F}=71.119$, $\mathrm{df}$ $=6.150, \mathrm{P}<0.001)($ Table 1$)$. 
Table 1. Mortality (\%) (mean \pm sd) of $\mathrm{H}$. armigera larvae after 3, 6, and 9 days due to treatment with entomopathogenic fungi (n = 100) at doses $\left(10^{3}, 10^{4}, 10^{5}, 10^{6}, 10^{7}, 10^{8}\right.$ conidia / ml) and control $\left(\mathrm{H}_{2} \mathrm{O}+\right.$ Tergitol NP9 $\left.0.05 \%\right)$. The different letters indicate statistically significant differences between the concentrations $(\mathrm{P}<\mathbf{0 . 0 5})$, and the asterisk indicates statistically significant differences from the control

\begin{tabular}{|c|c|c|c|c|}
\hline Treatment/Mortality & Concentration & 3 days & 6 days & 9 days \\
\hline \multirow{6}{*}{ B. bassiana } & $10^{3}$ & $0 \mathrm{c}$ & $17 \pm 5.8 * \mathrm{c}$ & $30 \pm 10 * \mathrm{c}$ \\
\hline & $10^{4}$ & $0 \mathrm{c}$ & $23 \pm 5.8 * \mathrm{c}$ & $43 \pm 5.8 * \mathrm{c}$ \\
\hline & $10^{5}$ & $0 \mathrm{c}$ & $33 \pm 15.3 * b c$ & $67 \pm 5.8 * b$ \\
\hline & $10^{6}$ & $3.4 \pm 5.8 * b$ & $40 \pm 10 * b$ & $80 \pm 10^{* a}$ \\
\hline & $10^{7}$ & $10 \pm 10 * \mathrm{a}$ & $73 \pm 11.5 * a$ & $93 \pm 11.5 * \mathrm{a}$ \\
\hline & $10^{8}$ & $23 \pm 15.3 * \mathrm{a}$ & $83 \pm 15.3 * a$ & $97 \pm 5.8 * a$ \\
\hline \multirow{8}{*}{ M. robertsii } & $10^{3}$ & 0 & $7 \pm 5.8 * d$ & $23 \pm 5.8 * \mathrm{e}$ \\
\hline & $10^{4}$ & $3.4 \pm 5.8 * \mathrm{a}$ & $27 \pm 11.5 * \mathrm{c}$ & $47 \pm 15.3 * d$ \\
\hline & $10^{5}$ & $3.4 \pm 5.8 * \mathrm{a}$ & $33 \pm 15.3 * \mathrm{c}$ & $57 \pm 15.3 * d$ \\
\hline & $10^{6}$ & $3.4 \pm 5.8 * \mathrm{a}$ & $43 \pm 5.8 * \mathrm{c}$ & $77 \pm 5.8 * \mathrm{c}$ \\
\hline & $10^{7}$ & $10 \pm 10 * \mathrm{a}$ & $67 \pm 11.5 * b$ & $87 \pm 5.8 * \alpha b$ \\
\hline & $10^{8}$ & $20 \pm 0 * \mathrm{a}$ & $90 \pm 10 * a$ & $97 \pm 5.8 * a$ \\
\hline & $10^{3}$ & 0 & $10 \pm 10 * b c$ & $17 \pm 5.8 * \mathrm{~d}$ \\
\hline & $10^{4}$ & $10 \pm 10 \mathrm{ab} *$ & $23 \pm 11.5 * b$ & $40 \pm 10 * \mathrm{c}$ \\
\hline \multirow{4}{*}{ I. fumosorosea } & $10^{5}$ & $6.7 \pm 5.8 b^{*}$ & $30 \pm 0 * \mathrm{~b}$ & $50 \pm 0 * \mathrm{c}$ \\
\hline & $10^{6}$ & $10 \pm 10 \mathrm{ab} *$ & $40 \pm 10 * b$ & $70 \pm 10 * b$ \\
\hline & $10^{7}$ & $20 \pm 0 a^{*}$ & $83 \pm 20.8 * a$ & $93 \pm 5.8 * a$ \\
\hline & $10^{8}$ & $13 \pm 5.8 b^{*}$ & $86.7 \pm 5.8 * \mathrm{a}$ & $100 * \pm 0.0 \mathrm{a}$ \\
\hline Control & $\mathrm{H}_{2} \mathrm{O}+$ Tergitol Np9 & 0 & $2.7 \pm 1.9$ & $4 \pm 1.3$ \\
\hline
\end{tabular}

Literature is abundant in studies which display the high virulence of entomopathogenic fungi. Such is the case of adults of Bactrocera zonata (Saunders) (Diptera: Tephritidae) which had been exposed to the conidia of L. lecanii, M. anisopliae and B. bassiana ${ }^{[29]}$. Additionally, Batta ${ }^{[30]}$ stated that high mortality in Rhyzopertha dominica F. (Coleoptera: Bostrichidae) was obtained after treatment with $\mathrm{M}$. anisopliae at 7 days. Wakefield et $\mathrm{a}^{[31]}$. reported $100 \%$ mortality of Ephestia kuehniella Zeller (Lepidoptera: Pyralidae) after 10 days of treatment with $10^{8}$ conidia $/ \mathrm{mL}$ of B. bassiana. Būda and Pečiulyte ${ }^{[32]}$ tested the effect of four fungal isolates (Beauveria bassiana, Lecanicillium lecanii, Metarhizium anisopliae var anisopliae and Paecilomycers farinosus) on adults of the Indian meal moth and all fungal isolates were pathogenic. Our results showed that the effectiveness of M. robertsii was on a par with that of the other two fungal species.

Moreover, Kaplan-Meier survival analysis (Wilcoxon-test) indicates the significant differences between the doses per concentration, according to the median survival time (Table 2). Literature indicates that some of the primary factors which can influence the efficacy of entomopathogens is the $\operatorname{dos}^{[33-35]}$, and abiotic factors such as temperature and relative humidity ${ }^{[3,37]}$. In our study, mean survival time adds to the indication that the effectiveness of the entomopathogenic fungi is proportionate to high conidial concentrations. The dose-dependency of mortality is in agreement with the results of other research studies, whereby application of entomopathogenic fungi at different doses has been significantly pathogenic, i.e. of the entomopathogenic Lecanicillium lecani to aphids Macrosiphum euphorbiae and Aphis gossypii ${ }^{[38]}$, to L. psalliotailephidus (I) ${ }^{[39]}$, of M. robertsii to thrips of the species Frankliniella occidentalis ${ }^{[40]}$ and to the tick Rhipicephalus (Boophilus) annulatus (Ixodidae) ${ }^{[38]}$, of I. fumosorosea to potato larvae of Bemisia tabaci (Gennadius) ${ }^{[41]}$ and, finally, of B. bassiana to diptera, coleoptera, and the lepidopteran Plutella xylostella ${ }^{[38,42-45]}$. It should be noted here that actual per os infection is very difficult to distinguish from infection resulting from spores that came into direct contact with the insect ${ }^{[45]}$. 


\begin{tabular}{|c|c|c|c|c|}
\hline & Treatment & & & Mean survival time \\
\hline \multirow[t]{18}{*}{ Pathogenic } & B. bassiana & Concentration & $10^{3}$ & 8.57 \\
\hline & & & $10^{4}$ & 8.31 \\
\hline & & & $10^{5}$ & 8.09 \\
\hline & & & $10^{6}$ & 7.82 \\
\hline & & & $10^{7}$ & 6.89 \\
\hline & & & $10^{8}$ & 6.13 \\
\hline & M. robertsii & & $10^{3}$ & 8.33 \\
\hline & & & $10^{4}$ & 8.10 \\
\hline & & & $10^{5}$ & 8.02 \\
\hline & & & $10^{6}$ & 7.60 \\
\hline & & & $10^{7}$ & 7.12 \\
\hline & & & $10^{8}$ & 6.29 \\
\hline & I. fumosorosea & & $10^{3}$ & 8.81 \\
\hline & & & $10^{4}$ & 8.62 \\
\hline & & & $10^{5}$ & 7.11 \\
\hline & & & $10^{6}$ & 6.89 \\
\hline & & & $10^{7}$ & 6.42 \\
\hline & & & $10^{8}$ & 5.50 \\
\hline
\end{tabular}

Beauveria bassiana, I. fumosorosea and M. anisopliae have wide host ranges, including major insect orders ${ }^{[46]}$. Different strains of Beauveria, Isaria and Metarhizium spp. are known to vary in virulence and other pathogenicity-related characteristics $^{[47]}$. Our study showed no significant differences between the three fungal species in terms of their effect on the treated larvae. At nine days, all three species induced high levels of mortality which differed significantly from the control. Moreover, M. robertsii was equal in effectiveness to the other two fungi. This is an encouraging result which expands our knowledge of the action of entomopathogenic fungi in the control of H. armigera.

\section{References}

[1] Vega FE, Goettel MS, Blackwell M, Chandler D, Jackson MA, Keller S, Koike M, Maniania NK, Monzo'n A, Ownley BH, Pell JK, Rangel DEN, Roy HE. Fungal entomopathogens: new insights on their ecology. Fungal Ecology. 2009; 2: $149-159$

[2] Mantzoukas S, Lagogiannis I, Mpekiri M, Pettas I, Eliopoulos P. Insecticidal action of several isolates of entomopathogenic fungi against the granary weevil Sitophilus granarius. Agriculture. 2019; 9 (10): 222.

[3] Mantzoukas S, Eliopoulos P. Endophytic Entomopathogenic Fungi: A Valuable Biological Control Tool against Plant Pests. Applied Science, SI: Endophytic Entomopathogenic Fungi: New approach for controlling serious pests. Applied Science. 2020; 10 (1): 370//doi.org/10.3390/app10010360.

[4] Butt TM. Use of entomogenous fungi for the control of insect pests. In: Kempken F. (eds) Agricultural Applications. The Mycota (A Comprehensive Treatise on Fungi as Experimental Systems for Basic and Applied Research), vol 11. Berlin: Springer; 2002.

[5] Hajek AE, McManus ML, Delalibera Jr. I. A review of introductions of pathogens and nematodes for classical biological control of insects and mites. Biological Control. 2007; 41: 1-13.

[6] Xiong Q, Xie Y, Zhu Y, Xue J, Li J, Fan R. Morphological and ultrastructural characterization of Carposina sasakii larvae (Lepidoptera: Carposinidae) infected by Beauveria bassiana (Ascomycota: Hypocreales: Clavicipitaceae). Micron. 2012; 44: 303-311.

[7] Gillespie AT, Bailey AM, Cobb B, Vilcinskas A. Fungi as elicitors of insect immune responses. Archives of Insect Biochemistry and Physiology. 2000; 44: 49-68.

[8] Vey FE, Hoagland R, Butt TM. Toxic metabolites of fungal biological control agents. In; Butt, T. M., Jackson, C., Magan, N. (eds). Fungi as biocontrol agents: progress, problems and potential. Wallingford, Oxon: Cab International. 2001. 
[9] Humber RA. Fungal Pathogens of Aphids. Proceedings of an OSU Centennial Event. 1991.

[10] Shahid AA, Rao QA, Baskhsh A, Husnain T. Entomopathogenic fungi as biological controllers: new insights into their virulence and pathogenicity. Archives of Biological Sciences. 2012; 64(1): 21-42.

[11] Hajek AE. Food consumption by Lymantria dispar (Lepidoptera: Lymantriidae) larvae infected with Entomophaga maimaiga (Zygomycetes: Entomophthorales). Environmental Entomology. 1989; 18: 723-727.

[12] Hussain A, Tian M, He Y, Ahmed S. Entomopathogenic fungi disturbed the larval growth and feeding performance of Ocinara varians (Lepidoptera: Bombycidae) larvae. Insect Science. 2009; 16: 511-517.

[13] Sierotzki H, Camastral F, Shah PA, Aebi M, Tuor U. Biological characteristics of selected Erynia neoaphidis isolates. Mycological Research. 2000; 104: 213-219.

[14] Pell JK., Eilenberg J, Hajek AE, Steinkraus DC. Biology, ecology and pest management potential of Entomophthorales. Wallingford: CAB International; 2001.

[15] Shaw KE, Davidson G, Clark SJ, Ball BV, Pell JK, Chandler D, Sunderland K D. Laboratory bioassays to assess the pathogenicity of mitosporic fungi to Varroa destructor (Acari: Mesostigmata), an ectoparasitic mite of the honeybee, Apis mellifera. Biological Control. 2002; 24: 266-276.

[16] Akbulut S, Yuksel B and Keten A. The Lepidoptera (INSECTA) Fauna of Düzce Province, Turkey. Turkish Journal of Zoology. 2003; 27(4): 257-268.

[17] Fitt GR. The ecology of Heliothis species in relation to agrosystems. Annual Review of Entomology. 1989; 34 : 17-52.

[18] Cunningham JR, Jallow MFA, Wright DJ, Zalucki MR. Learning in host selection in Helicoverpa armigera (Hübner) (Lepidoptera: Noctuidae). Annual Behaviour. 1998; 55: 227-234.

[19] Cunningham JR, West SA, Wright DJ. Learning in nectar foraging behaviour in Helicoverpa armigera (Hübner) (Lepidoptera: Noctuidae). Journal of Experimental Biology. 1998; 200: 2969-2976.

[20] Samson RA, Evans HC, Latgé JP. Atlas of entomopathogenic fungi. Springer Science \& Business Media; 2013.

[21] Shah PA, Pell JK. Entomopathogenic fungi as biological control agents. Applied microbiology and biotechnology. 2003; 61(5-6): 413-423.

[22] McGuire AV, Northfield TD. Tropical occurrence and agricultural importance of Beauveria bassiana and Metarhizium anisopliae. Frontiers in Sustainable Food Systems. 2020; 4: 6. doi: 10.3389/fsufs.

[23] Mora MAE, Rouws JRC, Fraga ME. Occurrence of entomopathogenic fungi in Atlantic forest soils. Microbiology Discovery. 2016; 4(1): 1 .

[24] Mantzoukas S, Pettas I. and Lagogiannis I. Stored product pests as models for trapping entomopathogenic fungi from olive tree orchards in Western Greece. Journal of Stored Product Research. 2020; 87: 101584, https://doi.org/10.1016/ j.jspr. 2020.101584.

[25] Quesada-Moraga E, Navas-Cortez JA, Maranhao EAA., Ortiz-Urquiza A, Candido S-A. Factors affecting the occurrence and distribution of entomopathogenic fungi in natural and cultivated soils. Mycological Research. 2007; 3: 947-966.

[26] Mantzoukas S. The effect of Metarhizium robertsii and Bacillus thuringiensis against Helicoverpa armigera (Hübner) (Lepidoptera: Noctuidae). Advances in Ecological and Environmental Research. 2019. p.136-146

[27] Abbott WS. A method of computing the effectiveness of an insecticide. Journal of Economic Entomology. 1925; 18: 265-267.

[28] Kurstak E. Microbial and Viral Pesticides. New York: Markel Dekker, Ink. 1982.

[29] Mahmoud F. Susceptibility of the peach fruit fly, Bactrocera zonata (Saunders), (Diptera: Tephritidae) to three entomopathogenic fungi. Egyptian journal of pest control. 2009; 19(2): 169-175.

[30] Batta YA, Abu Safieh DI. A study of treatment effect with Metarhizium anisopliae and four types of dusts on wheat grain infestation with red flour beetles (Tribolium castaneum Herbs, Coleoptera: Tenebrionidae). The Islamic University of Gaza Journal. 2005; 13: 11-22.

[31] Wakefield ME, Cox PD, Moore D, Aquino De Muro M, Bell BA. Mycopest: Results and perspectives. Proceedings of the 6th Meeting of COST Action 842 Working Group IV Biocontrol of Arthropod Pests in Stored Products. Locorotondo, Italy; 2005.

[32] Būda V, Pečiulytè D. Pathogenicity of four fungal species to Indian meal moth Plodia interpunctella (Hübner) (Lepidoptera: Pyralidae). Ekologija. 2008; 54: 265-270.

[33] Vega FE, Posada F, Aime MC, Pava-Ripoll M, Infante F, Rehner SA. Entomopathogenic fungal endophytes. Biological Control. 2008; 46: 72-82.

[34] Rodrigues C, Pratissoli D. Patogenicidade de Beauveria brongniartii (Sacc) Petch. e Metarhizium anisopliae (Mots.) Sorok. e seu efeito sobre o gorgulho do milho e caruncho do feijaÄ. Anais da Sociedade Entomological do Brasil. 19: 301-306.

[35] Hidalgo E, Moore D, Le Patourel, G. The effect of different formulations of Beauveria bassiana on Sitophilus zeamais in stored maize. Journal of Stored Product Research. 1998; 34: 171-179. 
[36] Moino Jr. A, Alves SB, Pereira RM. Efficacy of Beauveria bassiana (Balsamo) Vuillemin isolates for control of storedgrain pests. Journal of Applied Entomology. 1998; 122, 301-305.

[37] Luz C, Fargues J. Effects of fluctuating moisture and temperature regimes on sporulation of Beauveria bassiana on cadavers of Rhodnius prolixus. Biocontrol Science and Technology. 1998; 8 (3): 323-334.

[38] Gurulingappa P, McGee, PA, Sword G. Endophytic Lecanicillium lecanii and Beauveria bassiana reduce the survival and fecundity of Aphis gossypii following contact with conidia and secondary metabolites. Crop Protection. 2011; 30: 349-353.

[39] Khodadad PK, Hamidreza H, Mehdi RA, Saeed B, Rasoul Z, Mehran G, Masoomeh S.-G. Biological control of Rhipicephalus (Boophilus) annulatus by different strains of Metarhizium anisopliae, Beauveria bassiana and Lecanicillium psalliotae fungi. Parasitology Research. 2007; 100: 1297-1302.

[40] Sengonca C, Thungrabeab M, Blaeser P. Potential of different isolates of entomopathogenic fungi from Thailand as biological control agent against western flower thrips, Frankliniella occidentalis (Pergande) (Thysanoptera: Thripidae). Journal of Plant Diseases and Protection. 2006; 113: 74-80.

[41] Panyasiri C, Attathom T, Poehling HM. Pathogenicity of entomopathogenic fungi-potential candidates to control insect pests on tomato under protected cultivation in Thailand. Journal of Plant Diseases and Protection. 2007 ; 114 (6): 278-287.

[42] Fernandez S, Groden E, Vandenberg JD, Furlong MJ. The effect of mode of exposure to Beauveria bassiana on conidia acquisition and host mortality of colorado potato beetle, Leptinotarsa decemlineata. Journal of Invertebrate Pathology. 2001; 77: 217-226.

[43] Maciel MV, Luna-Alves Lima EA, Alves ND, Feijó FMC. Action of Beauveria bassiana on the post-embryonyc development of Cochliomyia macellaria (Diptera, Calliphoridae) in laboratory. Caatinga. 2005; 18: 1-5.

[44] Godonou I, James B, Atcha-Ahowe C, Vodouhe S, Kooyman C, Ahanchede A, Korie S. Potential of Beauveria bassiana and Metarhizium anisopliae isolates from Benin to control Plutella xylostella L. (Lepidoptera: Plutellidae). Crop Protection. 2009; 28: 220-224.

[45] Amora SSA., Bevilaqua CML, Carneiro Feijó FM, Silva MA, Pereira RHMA, Silva SC, Alves ND, Freire FAM, Oliveira DM. Evaluation of the fungus Beauveria bassiana (Deuteromycotina: Hyphomycetes), a potential biological control agent of Lutzomyia longipalpis (Diptera, Psychodidae). Biological Control. 2009; 50: 329-335.

[46] Humber RA, Hansen S. Hosts by fungal species. USDA-ARS Plant Protection Research Unit US Plant, Soil and Nutrition Laboratory. Ithaca, NY; 2004.

[47] Anderson D, Bell AS, Blanford S, Paaijmans KP, Thomas MB. Comparative growth kinetics and virulence of four different isolates of entomopathogenic fungi in the house fly (Musca domestica L.). Journal of Invertebrate Pathology. 2011; 107: 179-184. 